\title{
The Phenomenon of Intrusive Thoughts in Yejide Kilanko's Daughters Who Walk This Path
}

Shamaila Dodhy*

Department of English, University of the Punjab, Pakistan

Corresponding Author: Shamaila Dodhy, E-mail: shamailadodhy@yahoo.com

\section{ARTICLE INFO}

Article history

Received: June 24, 2017

Accepted: September 26, 2017

Published: October 31, 2017

Volume: 8 Issue: 5

Advance access: October 2017

Conflicts of interest: None

Funding: None

Key words:

Anxiety

Feeling

Pain

Past

Trauma

\begin{abstract}
Hegemonic masculinity, with patriarchal supremacy and female subservience are the norms of many African societies. Suffering in silence goes along with the traditional place of woman in African societies as they observe sexist hierarchy of power. Physical attack and its wounds flourish in an atmosphere of secrecy and silence. Silence to such problems escalates psychological distress, casting adverse effects on the individual. Silence leaves overt and covert markings on the psyche. Intrusive thoughts are one of symptoms among nightmares, flashbacks, fear, and anxiety of psychological trauma. No previous research examined the intrusion of intrusive thoughts which disturb the life of Morayo. The article addresses this gap as this symptom of trauma makes life difficult for a girl whose trust is violated by a kinsman. This work accentuates that speaking-out can end a false sense of shame that survivors often carry. Speech will agitate legal change, bring about advancement in therapeutic approaches, and undermine social myths about sexual assault which will promote acceptance for the survivors.
\end{abstract}

\section{INTRODUCTION TO THE STUDY}

In Daughters Who Walk This Path, Kilanko highlights Nigerian women's emotional strength, and their collective efforts to reduce the afflictions that women have to bear in the African society. The novel gives the marginalized teenager a control over the narrative expression thus shifting conventional notions of authority while giving immediacy to the narrative voice. The present study aims to analyze the protagonist of the selected text who experiences intrusive thoughts which are hostile and invasive. They are rather illogical, counterintuitive, and jumbled up. They cause discomfort resulting in anxiety and disgust for the perpetrator.

\section{METHODOLOGY}

The present study attempts to analyse the character of Morayo in light of leading trauma theorists. It aims to examine the phenomenon of intrusive thoughts, one of the intrinsic symptoms of psychological trauma. Morayo verifies compound signs of psychological trauma as the literary text develops. This happens because the mother of Morayo does not encourage the daughter to disclose her painful secrets to her. Instead of forgetting the traumatic experience; the intrusive thoughts interfere with her thought processes, thus contami-nating her mental health.

\section{TEXTUAL ANALYSIS}

Time is not reducing the anger and anxiety of Morayo. Her life is overwhelmed by intrusive thoughts which are involuntary and unpleasant. They are debilitating and distressing so Morayo is finding hard to manage them. The mother of Morayo though notices the changed behaviour of the daughter but she does not ask her the reason, thinking that it is quite normal for teenagers to be lost in day-dreams. She fails to realize the cause of worrisome attitude of her daughter. Consequently, Morayo's worries do not end here. Bros T continues abusing her over and over again on the threat that if she will not come to him, he will rape her younger sister too. He used to call her even in his own bedroom to assault her. His presence in the home is a constant source of threat to her. She wants to protect her sister at all costs because she cannot afford that her sister may go through the same trauma of which she has been through and is still going through.

Though still a child, but she experiences extreme listlessness as she cannot even enjoy good food. One night her mother cooked drumsticks which she used to eat with pleasure, but these days even good food does not please her. She eats in silence as if "eating moulded sawdust" (77). She cannot enjoy anything. She is going through such a traumatic state of mind that nothing pleases her. On finding her weak, 
Bros $\mathrm{T}$ is exploiting her by repeatedly abusing her. He knows her weak point, that she will let herself exploited in love of her younger sister. Judith Herman says that repeated trauma in childhood forms and deforms the personality. She continues,

The child trapped in an abusive environment is faced with formidable tasks of adaptation. She must find a way to preserve a sense of trust in people who are terrifyingly unpredictable, power in a situation of help-lessness. Unable to care for or protect herself, she must compensate for the failures of adult care and protection with the only means at her disposal, an immature system of psychological defenses. (1992, 96)

The only time Bros $\mathrm{T}$ feels panicked when Morayo gets pregnant of which she has no idea. He forces her to take tablets which she throws out of her mouth just to punish him. She is so innocent that she is completely unaware of the consequences of the pregnancy. It was her good luck which saved her from this catastrophe as one day as she was coming from school adopting a short-cut; she comes across two labourers who look at her. As she has been through such horrific experiences at such an early age so she starts running, thinking that these men are also chasing to molest her. Being so harassed, she falls into an open gutter which results in abortion. After heavy bleeding, she feels extremely tired and exhausted. As soon as her head touches the pillow, she falls into a deep sleep.

She is so unhappy with her life that she feels as if time has become too slow. Normally people say that time flies but for Morayo time "dragged on painfully" (82). Day by day the burden is getting heavier than before. She has become "tired of the silent screams in [her] head" (82). One day on finding Bros $\mathrm{T}$ crossing limits with her younger sister in touching and teasing, she stares at him. She is surprised to find the same evil expression on his face for her sister which she sees for herself. While Eniayo is washing dishes in the sink, he rubs himself with her back. With hands in soapy water, she cannot resist him, so she pushes him with her elbow. This aggravates the anger of Morayo as she is letting herself exploited just for the sake of her younger sister, but now he is approaching her right in front of everyone, posing as if he is very loving brother who takes care of his younger sisters. Her traumatic state of mind cannot be understood by anyone. The past haunts her. She remains so lost in her intrusive thoughts that she breaks the plate which she was holding in her hand. About traumatic memories, Anne Whitehead says,

Traumatic recollection is characterised by the striking paradox that while its re-enactments are disturb-ingly literal and precise, they nevertheless remain large-ly unavailable to conscious recall and control. Although the event returns in a vivid and precise form in the trau-matic nightmare or flashback, it is simultaneously ac-companied by amnesia. $(2004,140)$

On the same night, on the dining table she discloses the secret to her parents which was not less than an explosion for them. The father's blood pressure shoots up so high that his gums start bleeding.

Immediately her mother's eyes are filled with tears but she does not come forward to say a word of consolation to the daughter. She does not even look at Morayo due to which she feels that her "anger towards Mummy reignited" (84) because she should have consoled her broken child who is undergoing through terrible pain. Instead of feeling worried about Morayo, she completely ignores her presence. On finding this reaction of mother, she wants to scream and shout to make her realize that the pain she is undergoing is because of her nephew. To her surprise, when her parents return after dropping Bros $\mathrm{T}$ to his home, they do not soothe her at all. The father looks at her with a tired face but to her surprise the mother stares at her with "bloodshot eyes" (89). Then when father walks towards staircase to go into his bedroom, the mother's looks at Morayo with red eyes filled with fresh tears. She sighs and leaves the room. At this point, Morayo wishes to be embraced and kissed. She wishes that her mother may ask questions to her like what happened and how it happened, but not a single word of solace comes out of her mouth. Her heart-beat increases and she feels as if it will break apart but she finds no shoulder where she can put her head to cry.

The mother of Morayo is ignoring her daughter's feelings as if nothing unusual has happened. She should fight on her own out of this traumatic situation which is not possible for such a young girl who has come across trauma which is far more disturbing than if she would have been assaulted by the labourers working in the under-construction building. The mother is avoiding discussing the matter due to which there is a continuous negotiation going on within her with her past. She wants her mother to discuss the issue with her but at the same time she wants to stay alone; she does not want to go to family gatherings. Due to intense stress, she has started having migraines which the mother thinks that a tablet of pain-killer will cure her. Failing to get attention of mother, she decides to kill herself by taking a bottle full of medicine. She thinks that death will free her from the traumatic pain which she is undergoing for such a long time. She feels as if her soul is trapped inside heavy body so she wishes to feel free. The experimental studies on child sex abuse of Van der Kolk "demonstrate that histories of childhood physical and sexual abuse, as well as paren-tal neglect and separations, are strongly correlated with a variety of self-destructive behavior in adulthood, including suicide attempts and cutting" (1991, 1669).

The anxiety of Morayo does not decrease with the passage of time. On the contrary, as the time passes by, Morayo feels as if "the dark cloud surrounding [her] [grows] even bigger" (93). She has to live "a double life" (89). At school, she has to pretend that everything is fine and normal and at home she could not face her parents whose eyes are asking "unasked questions?" (90). She feels that they want to ask her why she has delayed the step of disclosing this secret to her parents, why she let that evil man inflict trauma on her? But they never ask their daughter any such question directly. 
However their questioning looks are quite painful for her. She wants to narrate her pain to her parents because "narration cures, it does so not because it infallibly gives the patient access to a primordially personal truth but because it makes possible a form of self-understanding even in the absence of empirical verification" (Leys, 2000, 117).

The pain increases in intensity as she finds her younger sister is being sent to boarding school because after Morayo's experience the parents feel that living in boarding school will teach her independence and she will learn to take care of herself. The separation from her sister is very painful. To express her feelings for her sister, she says that she is not crying but it is "raining inside [her] eyes" (92). After the departure of her sister and aunt Adunni who has stayed with them for ten years, her feeling of loneliness intensified because parents have not talked or asked a single question about Bros $\mathrm{T}$ from her. The experience of pain caused by Bros $\mathrm{T}$ is not yet over, as she feels a "cold knot deep inside [her] that had come after that first night with Bros T pulled tight until [she] could barely breath from the pain" (95). It is a persistent pain because she wants to talk but cannot find anyone.

On shifting to the university hostel for higher studies, Morayo starts torturing herself by developing reckless attitude as she goes from one man to another. Sometimes she used to take it as a challenge and entice them to such an extent that they submit to her offers. She has been doing it out of anger which she has developed for the male gender after the inhuman treatment of Bros T. The pain of trauma is still there, though much time has elapsed. She is now in a new city, in a new environment, among new people but she cannot erase that painful experience from her mind which she has undergone when Bros $\mathrm{T}$ came first time to her bedroom to ravish her. People have started raising fingers on her. Her friends, mother and sister stop her from doing so but she is not ready to listen to anyone. It is like as if she is punishing herself by adopting such a reckless attitude. One night even the guard of the university hostel degrades and insults her by considering her worse than a prostitute. She has stigmatized her identity out of sheer frustration. His painful remarks enter her for the first time which makes her cry bitterly. For two days, she remains in her bed without eating, bathing or going to the campus to attend lectures. Suddenly she feels that she is the same little girl who tried to take pills to kill her. Herman says that it is misconception that growing up will resolve the trauma. She elucidates,

The emotional state of the chronically abused child ranges from a baseline of unease, through intermediate states of anxiety and dysphoria, to extremes of panic, fury, and despair. Not surprisingly, a great many survivors develop chronic anxiety and depression which persist into adult life. The extensive recourse to dis- sociative defenses may end up aggravating the abused child's dysphoric emotional state, from dissociative process sometimes goes too far. Instead of producing a protective feeling of detachment, it may lead to a sense of complete disconnection from others and disintegration of the self. $(1992,108)$

She feels so overwhelmed by these traumatic feelings that when she meets her first love, Kachi, she does not want to continue her relationship with him. She is in such a mental state that her voice chocked when she meets him. She wants to tell him all about her past but at the same time she is afraid of losing a good man. She is unable to decide what to do. She refuses to carry on any relationship with any man after being betrayed by Bros T. All her friends are getting married but whenever her mother asks her to find a suitable life partner for herself she feels her heart heavy and wants to run far away. Much time has passed but the feel of disgust is there. When she looks at her image in the mirror, she does not want to look at herself. She goes to her bed to lie there in "fetal position", which shows her intense sense of insecurity from which she is suffering. She wants to go back into that state when as an unborn child she was in the safest and the most secure mode of life. She considers herself to be guilty of the sin which someone else has committed. She has crossed her thirty-first birthday. Now even the peon in the office has started suggesting her to go to a certain fountain to pray for marriage. The societal pressure is getting too much on her nerves. She does not know whether to laugh or cry.

Kachi, a faithful and loving young man wants to marry Morayo even after knowing about her past. He truly loves her and wants to remain with her throughout her life. Fifteen years have passed since that traumatic incident but she cannot reconcile with the bitter truth that the incident has become a part of the past so it has to be forgotten to pass a normal life. Intrusive thoughts and nightmares do not leave her even after getting married to Kachi. Bros T's mother brings her grandchildren in a family gathering. When she looks at them, she finds her throat "suddenly start[s] itching" (290). She feels burning pain on seeing the off-springs of that man who has destroyed her life and peace of mind. On hearing that Bros $\mathrm{T}$ has also come to the gathering and is in the sitting room she feels as if her head has doubled in size. Fifteen years have passed, now both of them are settled in their professional and private lives, still she feels terrified as a small child. The protagonist describes her feelings, "As soon as I stepped into the sitting room and saw him, I felt as if I were submerged in water and my lungs deprived of oxygen" (292). Her condition is like that of a person drowning in deep waters where she can find no oxygen. She has been through this state of mind for almost two decades while the perpetrator is passing a very normal and luxurious life with no burden on his heart.

Morayo is working as a professional bank-officer. She has a potential to grow in her career but Bros $\mathrm{T}$ approaches her as client and forces the boss of Morayo that the officer in charge of his work should be Morayo. He forces the boss to bring Morayo to his house and then makes him leave his house to stay alone in the company of Morayo. On finding herself in the presence of the perpetrator, she gets terrified to 
such an extent that she runs away from the room and slips from the stairs. Bros T carries her to the hospital where she remains in coma for two days. This all happens because she cannot get rid of the feeling of trauma, though now she is no more a vulnerable school girl but a settled, married and qualified bank-officer. The husband forces her to resign immediately from the job because he cannot take the risk of losing the life of his wife anymore. Though she slips from stairs but fortunately the life of their unborn child is saved. The last message which she receives from aunt Morenike who has died in late thirties due to cancer, "My dear, please remember to be kind to yourself" (emphasis in original) (327). She suggests Morayo to forget the past and look ahead into the bright future which is waiting for her.

\section{CONCLUSION}

It is observed that for Morayo who is a trauma survivor, intrusive memories of traumatic experiences come at unexpected and unwanted times. They lack qualified information about the context. They are disjointed in contrast to other relevant information so the traumatic moments along with the corresponding emotions are re-experienced. Consequently, she loses contact with current reality and responds as if the trauma is happening at that moment which is very distressing. She should have been given an opportunity to be heard by her mother by letting her narrate the painful past which would have given her some solace.

\section{REFERENCES}

Herman-Lewis, J. (1992). Trauma and recovery: The aftermath of violence-from domestic abuse to political terror. New York: Basic Books.

Kilanko, Y. (2012). Daughters who walk this path. London: Penguin.

Leys, R. (2000). Trauma: A genealogy. Chicago: Chicago University Press.

Van der Kolk, B. A., Perry, J. C., \& Herman, J. L. (1991). Childhood origins of self-destructive behavior. The American Journal of Psychiatry, 148(12), 1665.

Whitehead, A. (2004). Trauma fiction. Edinburgh: Edinburgh University Press. 